\title{
Factors Influencing Customer Online Purchase Intention at Tokopedia.com
}

\author{
Rivan Ardyanto Sutoyo ${ }^{1}$, Maya Ariyanti ${ }^{2}$ \\ ${ }^{1,2}$ Telkom University, School of Business and Economics, Jl. Telekomunikasi Terusan Buah Batu Bandung 40257 Indonesia
}

\begin{abstract}
The high growth in number of internet users in Indonesia makes e-commerce become a promising business opportunities. Tokopedia, a pioneer for marketplace in Indonesia, has been around for 9 years and recently many competitor rise up and compete each other. Since 2013, purchase intention in Tokopedia increases along with the competitors and to keep maintain, Tokopedia must know about consumer behavior about what their needs and wants. This study aims to know factors that drive customer online purchase intention at Tokopedia.com. Quantitative research with causal type of study is used in the research. The studied samples were processed by method namely convenience sampling with total sampling of 400 respondents. Data collection method use questionnaire, were collected through google form across nations, and use SEM for data analysis techniques. The purchase intention of Tokopedia is mostly contributed by other user's influence comments in seller profile at Tokopedia. The result conclusion is all of factors affected purchase intention, e-wom among customer could lead the company to increase customer trust, to develop brand image of Tokopedia, and website features makes customer feel easy to do online shopping.
\end{abstract}

Keywords: E-commerce, Consumer Behaviour, Purchase Intention.

\section{Introduction}

Internet growth and developments have created new channels and innovations in business. E-commerce is born along with that change. Internet user in Indonesia has reached 132.7 million with the penetration of rate of $51.8 \%$, the number surpass actual total population number of 250 million ${ }^{[1]}$. The high growth in number of internet users in Indonesia makes e-commerce become a promising business opportunities.

Tokopedia is a an online marketplace that enables individuals and business owners to open and maintain their online stores for free pioneer for marketplace in Indonesia, has been around for 9 years. Founded in 2009, Tokopedia has grown rapidly to become one of Indonesia's leading online marketplaces. Following the investment, Tokopedia will focus on customer acquisition, hiring, and other initiatives to further strengthen its position in Indonesia. It claims to be the number one online marketplace in Indonesia. "In the Asia region, the growth potential for online marketplaces particularly stands out in Indonesia, and since their founding, Tokopedia has seen remarkable growth with their innovative business model," added Nikesh Arora, vice chairman of SoftBank and CEO of SIMI ${ }^{[2]}$. In 2014, Tokopedia has delivered 3 million products per month ${ }^{[3]}$, in 2015 total 6 million product per month ${ }^{[4]}$, and last in 2017 CEO William Tanuwijaya said total 13.5 million product delivered per month ${ }^{[5]}$.

It indicates that every year purchase intention in Tokopedia is increase because of total quantity product delivered increase also. On the other hand, many e-commerce rise up after Tokopedia. Therefore, Tokopedia should think about the strategy to keep their existing customers from moving to another e-commerce. In order to keep their customers, Tokopedia need to remain competitive by providing users with knowing factors that affected purchase intention in their website. Based on previous explanation, this study is intended to analyze factors that affected customer purchase intention.

\section{Literature Review}

\section{Brand Image}

Brand as a name, sign, symbol, or design, or a combination of them, intended to identify, the goods or services of one seller or group of sellers and to differentiate them from those of competitors ${ }^{[6]}$. Brand image influences purchase intention and play a moderating role between e-wom and purchase intention ${ }^{[7]}$.

\section{Trust}

The dimension of a business relationship that determines the level to which each party feels they can rely on the integrity of the promise offered by the other ${ }^{[8]}$.

\section{E-wom}

There are four dimension of e-wom: (1) intensity, (2) positive valance, (3) negative valance, (4) content ${ }^{[9]}$.

\section{Website Features}

Web features: it is a factor that is defined differently by different researchers ${ }^{[10]}$. Web features include factors like ease of navigation, the professionalism of the Website or user interface quality ${ }^{[11]}$. Web feature is a group including categories of privacy, security, and pleasure site ${ }^{[12]}$

\section{Perceived Ease of Use}

Perceived ease of use (PEU) is the degree to which the user expects the target system to be free of efforts ${ }^{[13]}$. PEU is variable in Technology Acceptance Model (TAM). TAM is found to be suitable for situations involving social pressure in adopt technology, therefore it maybe apply to online purchasing setting. TAM has been widely applied to a diverse set of technologies and users ${ }^{[10]}$.

Purchase Intention

Online purchase intention can be defined as a situation where 


\section{International Journal of Science and Research (IJSR) \\ ISSN (Online): 2319-7064}

Index Copernicus Value (2015): 78.96 Impact Factor (2015): 6.391

a consumer is willing and intends to make online transactions ${ }^{[14]}$. This term is used when customers willingness to search, select and purchase products via the Internet.

\section{Methodology}

This research use quantitative type and data were collected via questionnaire with a period time and it is using Likert Scale.

\subsection{Research Framework}

Based on existing literature about purchase intention, this framework is constructed to illustrate factors affecting purchase intention:

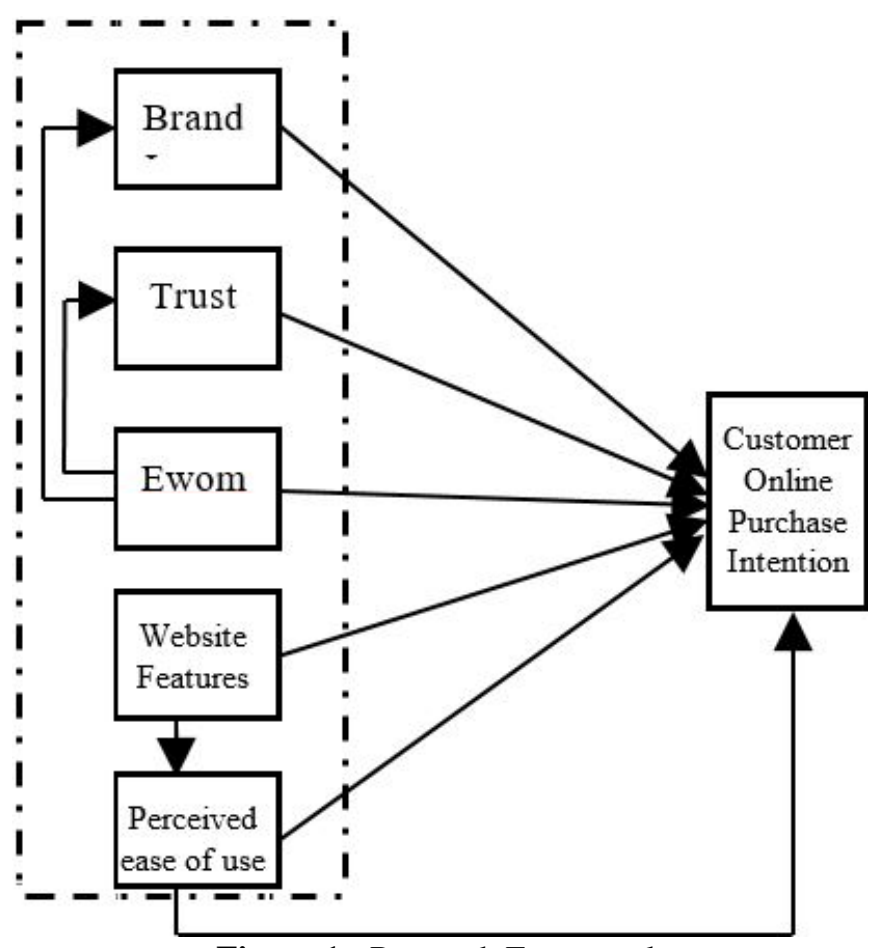

Figure 1 : Research Framework

The hypothesis that will be tested is as follow:

H1 : There's significant influence of brand image toward customer online purchase intention.

H2 : There's significant influence of trust toward customer online purchase intention.

H3 : There's significant influence of e-wom toward customer online purchase intention.

H4 : There's significant influence of website features toward customer online purchase intention.

H5 : There's significant influence of perceived ease of use toward customer online purchase intention.

H6 : There's significant influence of website features toward perceived ease of use.

H7 : There's significant influence of e-wom toward trust.

H8 : There's significant influence of e-wom toward brand image.

H9 : There's significant influence of brand image, trust, ewom, website features, perceived ease of use toward customer online purchase intention.

\subsection{Data Collection}

Data were distributed through social media with total 400 respondents. The collected data analyzed using Excel and it kept confidentially. This research using convenient sampling based on accessibility and availability of respondents. The data were distributed both male and female to avoid gender imbalanced. The requirement to participate this questionnaire are have questionnaire link and know Tokopedia is online shopping place.

Table 3.1: Demographic characteristics of respondents

\begin{tabular}{|c|c|c|}
\hline Characteristic & Frequency & Percentage \\
\hline \multicolumn{3}{|l|}{ Age } \\
\hline $15-19$ & 28 & $7 \%$ \\
\hline $20-24$ & 266 & $66.5 \%$ \\
\hline Above 25 & 106 & $26,5 \%$ \\
\hline \multicolumn{3}{|l|}{ Gender } \\
\hline Male & 205 & $51 \%$ \\
\hline Female & 195 & $49 \%$ \\
\hline \multicolumn{3}{|c|}{ Frequently Access Websites per month } \\
\hline$<4$ times & 221 & $55,25 \%$ \\
\hline 5-9 times & 100 & $25 \%$ \\
\hline$>10$ times & 79 & $19,75 \%$ \\
\hline \multicolumn{3}{|c|}{ Average online shopping expenditure } \\
\hline$<$ Rp. $100.000,00$ & 173 & $43,25 \%$ \\
\hline Rp. $100.000-$ Rp. 500.000,00 & 192 & $48 \%$ \\
\hline Rp. 500.000 - Rp. 1.000.000,00 & 20 & $5 \%$ \\
\hline > Rp. $1.000 .000,00$ & 15 & $3,75 \%$ \\
\hline
\end{tabular}

From the result of respondent's characteristic, it can be seen that the respondent based on the age of 400 respondents used as the sample, it can be concluded that the majority of consumers using Tokopedia aged 20-24 years as many as 266 people or $66.5 \%$. Then, percentage results show that between male and female consumers visiting Tokopedia website is not limited to gender but still dominated by male $51 \%$. Also the majority of consumer's accesses Tokopedia website lower than 4 times. Last, the majority of consumers purchase online is $48 \%$ with average online shopping expenditure between Rp. $100.000,00$ - Rp. 500.000,00.

\section{Result and Discussions}

\subsection{Outer Model}

Data analysis techniques using Smart PLS 2.0 to test model. Measurement model is necessary to determine validity and reliability of this model. Validity test consists of convergent validity and discriminant validity. Convergent Validity will be stated as valid if value of Loading Factors of each indicators > 0.50 and Average Variance Extracted (AVE) > 0.50 for each construct. Discriminant Validity will be stated as valid if value of cross loading in which the value with its latent variable is bigger than value of other latent variable.

From table 4.4 below, all of indicators have loading factor value $>0.50$ and all of constructs have AVE $>0.50$, thus all indicators of constructs are valid for convergen validity. Also, all of cross loadings (the bold numbers) value is bigger than value of other latent variable, thus the model is accepted to fulfill requirements for discriminant validity.

\section{Volume 6 Issue 7, July 2017 www.ijsr.net}




\section{International Journal of Science and Research (IJSR) \\ ISSN (Online): 2319-7064}

Index Copernicus Value (2015): 78.96 | Impact Factor (2015): 6.391

Reliability measured by inferring to value of Composite Reliability (CR) and Cronbach's Alpha of each constructs. A construct can be stated as reliable if $\mathrm{CR}>0.70$ or can be accepted between 0.60-0.70 and Cronbach's Alpha $>0.70$. The following table contains all reliability value of this model:

Table 4.1: Reliability Model

\begin{tabular}{|c|c|c|c|}
\hline Construct & $\begin{array}{c}\text { Composite } \\
\text { Reliability }\end{array}$ & $\begin{array}{c}\text { Cronbachs } \\
\text { Alpha }\end{array}$ & Description \\
\hline BI & 0.775 & 0.889 & Reliable \\
\hline COPI & 0.770 & 0.879 & Reliable \\
\hline Ewom & 0.839 & 0.885 & Reliable \\
\hline PEOU & 0.756 & 0.893 & Reliable \\
\hline TR & 0.670 & 0.845 & Reliable \\
\hline WF & 0.701 & 0.842 & Reliable \\
\hline
\end{tabular}

All of constructs has Composite Reliability (CR) and Cronbach's Alpha Reliable. Thus it can be concluded this model is reliable.

\subsection{Inner Model}

Inner model is well known as structural model test. Structural test consists $\mathrm{R}^{2}$ to see how much independent variables can explain the dependent variable and $\mathrm{Q}^{2}$ to predictive relevance to estimates whether a model have predicting power or not.

Table 4.2 Inner Model Test

\begin{tabular}{|c|c|c|}
\hline Laten Endogen Construct & $\mathrm{R}^{2}$ & $\mathrm{Q}^{2}$ \\
\hline COPI & 0.539 & 0.395 \\
\hline
\end{tabular}

The value of $\mathrm{Q}^{2}$ can be stated as good of predicted relevance $\mathrm{Q}^{2}>0$. From following table, value of $\mathrm{R}^{2}$ for Customer Online Purchase Intention construct is 0.539 it means that all elements such as Brand Image, Trust, E-wom, Website Features, and Perceived Ease of Use can explain $53.9 \%$ of Customer Online Purchase Intention. The rest of it, $46.1 \%$ is influenced by other factors. The result of $\mathrm{Q}^{2}$ is above value 0 , it means that the model has predictive relevance. From all indicators it can be concluded that this model is acceptable.

\subsection{Hypothesis Testing}

In this research hypothesis is testing using two-tails method with significance level of $5 \%$. The requirement is accepted when $t$-statistic $\geq 1.96 ; \mathrm{p}$ value 0.05 and rejected when
Table 4.3: Hypothesis Testing $\mathrm{t}$

\begin{tabular}{|c|c|c|c|c|}
\hline Hypothesis & Path & $\begin{array}{c}\text { Path } \\
\text { Coefficient }\end{array}$ & t statistic & Description \\
\hline H 1 & BI -> COPI & 0.108 & 2.389 & Accepted \\
\hline H 2 & TR -> COPI & 0.115 & 1.977 & Accepted \\
\hline H 3 & EW -> COPI & 0.542 & 11.171 & Accepted \\
\hline H 4 & WF -> COPI & 0.197 & 3.621 & Accepted \\
\hline H 5 & PEOU -> COPI & 0.192 & 2.708 & Accepted \\
\hline H 6 & WF -> PEOU & 0.818 & 43.594 & Accepted \\
\hline H 7 & EW -> TR & 0.575 & 15.749 & Accepted \\
\hline H 8 & EW -> BI & 0.503 & 12.438 & Accepted \\
\hline
\end{tabular}

t-statistic <1.96; $\mathrm{p}$ value 0.05 . The value of path coefficient indicates positive or negative influence of latent exogen construct toward latent endogen construct. From the hypothesis $t$ tested, the results show that all of hypotheses are accepted. It is found that brand image positive significant influences customer online purchase intention, thus $\mathrm{H} 1$ is accepted. Also $\mathrm{H} 2$ is accepted, trust positive significance influences customer online purchase intention. E-wom (H3), Website Features (H4), and Perceived Ease of Use (H5) have positive significant influences customer online purchase intention. H6 is accepted, website features positive significant influences perceived ease of use. This study also proves that $\mathrm{H} 7$ accepted, e-wom positive significant influences trust, and $\mathrm{H} 8$ accepted, ewom positive significant influences brand image.

H9 is tested using this equation below, $\mathrm{H} 9$ accepted if $\mathrm{F}_{\text {research }}$ $\geq \mathrm{F}_{\text {table }}$, where $\mathrm{F}_{\text {table }}=\mathrm{F}_{(0,05 ; 5 ; 394)}=2,237$ and rejected if if $\mathrm{F}_{\text {research }}<\mathrm{F}_{\text {table }}$.

$$
F=\frac{R^{2} / k}{\left(1-R^{2}\right) /(n-k-1)}
$$

description :

$\mathrm{R}_{2}=\mathrm{R}$ Square

$\mathrm{k}=$ number of variabel exogen

$\mathrm{n}=$ number of sample

$$
F=\frac{0.539 / 5}{(1-0.539) /(400-5-1)}=92,133
$$

From analysis result, it shows that $F_{\text {research }} 92,133 \geq F_{\text {table }}$ 2,237. Thus H9 is also accepted, brand image, trust, e-wom, website features, and perceived ease of use positive significant influences customer online purchase intention.

\begin{tabular}{|c|c|c|c|c|c|c|c|c|c|c|}
\hline \multirow{2}{*}{$\begin{array}{c}\text { Latent } \\
\text { Variable }\end{array}$} & \multirow{2}{*}{ Indicator } & \multirow{2}{*}{$\begin{array}{l}\text { Loading } \\
\text { Factor }\end{array}$} & \multicolumn{6}{|c|}{ Cross Loading } & \multirow{2}{*}{ AVE } & \multirow{2}{*}{ Description } \\
\hline & & & BI & TR & EW & WF & PEOU & COPI & & \\
\hline \multirow{5}{*}{$\begin{array}{l}\text { Brand } \\
\text { Image }\end{array}$} & BI 1 & 0.874 & 0.874 & 0.463 & 0.456 & 0.488 & 0.516 & 0.460 & \multirow{5}{*}{0.694} & Valid \\
\hline & BI 2 & 0.886 & 0.886 & 0.436 & 0.456 & 0.468 & 0.481 & 0.442 & & Valid \\
\hline & BI 3 & 0.753 & 0.753 & 0.322 & 0.318 & 0.396 & 0.362 & 0.278 & & Valid \\
\hline & BI 4 & 0.88 & 0.880 & 0.519 & 0.476 & 0.520 & 0.522 & 0.494 & & Valid \\
\hline & BI 5 & 0.765 & 0.765 & 0.534 & 0.391 & 0.471 & 0.450 & 0.430 & & Valid \\
\hline \multirow{4}{*}{ Trust } & TR 1 & 0.759 & 0.365 & 0.759 & 0.378 & 0.514 & 0.453 & 0.419 & \multirow{4}{*}{0.681} & Valid \\
\hline & TR 2 & 0.814 & 0.423 & 0.814 & 0.434 & 0.524 & 0.482 & 0.415 & & Valid \\
\hline & TR 3 & 0.845 & 0.489 & 0.845 & 0.477 & 0.536 & 0.514 & 0.440 & & Valid \\
\hline & TR 4 & 0.88 & 0.530 & 0.880 & 0.571 & 0.552 & 0.575 & 0.532 & & Valid \\
\hline E-wom & EW 1 & 0.832 & 0.378 & 0.480 & 0.832 & 0.459 & 0.456 & 0.539 & 0.742 & Valid \\
\hline
\end{tabular}

Table 4.4: Validity Model 
International Journal of Science and Research (IJSR)

ISSN (Online): 2319-7064

Index Copernicus Value (2015): 78.96 | Impact Factor (2015): 6.391

\begin{tabular}{|c|c|c|c|c|c|c|c|c|c|c|}
\hline & EW 2 & 0.886 & 0.460 & 0.476 & 0.886 & 0.477 & 0.497 & 0.582 & & Valid \\
\hline & EW 3 & 0.874 & 0.416 & 0.478 & 0.874 & 0.470 & 0.499 & 0.549 & & Valid \\
\hline & EW 4 & 0.855 & 0.495 & 0.530 & 0.855 & 0.548 & 0.498 & 0.635 & & Valid \\
\hline \multirow{5}{*}{$\begin{array}{l}\text { Website } \\
\text { Features }\end{array}$} & WF 1 & 0.791 & 0.470 & 0.427 & 0.510 & 0.791 & 0.705 & 0.440 & \multirow{5}{*}{0.613} & Valid \\
\hline & WF 2 & 0.732 & 0.323 & 0.375 & 0.402 & 0.732 & 0.592 & 0.377 & & Valid \\
\hline & WF 3 & 0.773 & 0.451 & 0.591 & 0.428 & 0.773 & 0.607 & 0.489 & & Valid \\
\hline & WF 4 & 0.829 & 0.440 & 0.549 & 0.411 & 0.829 & 0.670 & 0.427 & & Valid \\
\hline & WF 5 & 0.789 & 0.518 & 0.568 & 0.472 & 0.789 & 0.631 & 0.509 & & Valid \\
\hline \multirow{5}{*}{$\begin{array}{c}\text { Perceived } \\
\text { Ease of Use }\end{array}$} & PEOU 1 & 0.889 & 0.487 & 0.519 & 0.497 & 0.746 & 0.889 & 0.546 & \multirow{5}{*}{0.703} & Valid \\
\hline & PEOU 2 & 0.904 & 0.531 & 0.559 & 0.500 & 0.738 & 0.904 & 0.564 & & Valid \\
\hline & PEOU 3 & 0.885 & 0.474 & 0.520 & 0.503 & 0.732 & 0.885 & 0.503 & & Valid \\
\hline & PEOU 4 & 0.759 & 0.442 & 0.472 & 0.373 & 0.620 & 0.759 & 0.369 & & Valid \\
\hline & PEOU 5 & 0.744 & 0.437 & 0.516 & 0.493 & 0.588 & 0.744 & 0.524 & & Valid \\
\hline \multirow{4}{*}{$\begin{array}{l}\text { Customer } \\
\text { Online } \\
\text { Purchase } \\
\text { Intention }\end{array}$} & COPI 1 & 0.861 & 0.423 & 0.427 & 0.546 & 0.473 & 0.514 & 0.861 & \multirow{4}{*}{0.734} & Valid \\
\hline & COPI 2 & 0.83 & 0.417 & 0.424 & 0.551 & 0.489 & 0.522 & 0.830 & & Valid \\
\hline & COPI 3 & 0.895 & 0.483 & 0.517 & 0.627 & 0.506 & 0.518 & 0.895 & & Valid \\
\hline & COPI 4 & 0.841 & 0.441 & 0.517 & 0.573 & 0.500 & 0.510 & 0.841 & & Valid \\
\hline
\end{tabular}

\subsection{Discussion}

From the result of respondent's characteristic, it can be seen that the respondent based on the age of 400 respondents used as the sample, it can be concluded that the majority of consumers using Tokopedia aged 20-24 years as many as 266 people or $66.5 \%$. Then the second position was filled by respondents with age $>25$ years as many as 106 people or $26.5 \%$. Respondents aged 15-19 years were 28 or $7 \%$. By looking at the characteristic outcomes of respondents by age, Tokopedia consumers are 20-24 years old, dominated by young adults who have just started their career or are studying as college students. Compared with data from the Association of Internet Service Providers Indonesia (APJII) on the age of Internet users in Indonesia, the percentage of the majority of Internet users in Indonesia aged 18-25 years is $49 \%$ or almost half of the total internet users in Indonesia.

Based on respondents male sex of 205 people or $51 \%$ and female respondents female by 195 people or $49 \%$ of the total respondents. Nearly close percentage results show that between male and female consumers visiting Tokopedia website is not limited to gender. Also the majority of consumer's access Tokopedia website lower than 4 times. Last, the majority of consumers purchase online is $48 \%$ with average online shopping expenditure between Rp. 100.000,00 - Rp. 500.000,00.

From all of outer model test, inner model test, it is found that this model is viable to be tested. Result from hypothesis testing shows that, e-wom and brand image influences purchase intention also e-wom influences brand image. This finding is consistent with previous research conducted by Jalilvand (2012). Also, trust influences purchase intention according to Wang et al. (2015), trust is influence on booking intention and e-wom influence trust, the influence of comments on trust in a hotel booking. Website features also influences purchase intention according to Wang et al (2015) and website features influences perceived ease of use in Chang et al (2015). Perceived ease of use also influences purchase intention according to Pavlou (2003).

However, despite the significant result, brand image's coefficient path result only $10.8 \%$, trust's coefficient path only $11.5 \%$ and lower than the other variables. Even though, they are positive significant influences purchase intention but it is in unstable number. Brand image and trust have no physically form but it is depend on a perception of someone. Different specify product of e-commerce may can generate different result for brand image and trust. According to Indonesia perspective mind, Ecommerce in Indonesia has a high growth potential. All the ingredients are there. Most importantly, it's a young, populous, and increasingly affluent nation. But, 59 percent of respondents said they haven't shopped online yet because they prefer to buy offline, and more than a third said they don't trust online shops. Only 10 percent said cheap prices would compel them to buy something online based on Macquarie cites a study coauthored by Indonesia's ecommerce association (iDEA), research firm MARS Indonesia, and marketing magazine SWA. Macquarie Research concludes that ecommerce players should work on things like improving delivery times, and more flexible return policies ${ }^{[17]}$. It indicates that future research must focus on how to build a positive trust and brand image using e-wom via online forum discussion.

\section{Recommendation}

Due to result in this research, although questionnaires were distributed across country through social media, the result is still majority respondent from Java. In the future, questionnaire can distribute to specific big cities in Indonesia. In term of lower result coefficient trust and brand image, company must focus on how to build a positive trust and brand image using e-wom via online forum discussion. For instance, company can provide a forum online discussion within the website or an alternative website. In field, the addition of website features that direct the website to the blog link tokopedia so that consumers are aware of it so that awakened confidence in the brand image of Tokopedia and in terms of consumers can feel the ease in transaction online because of the feature.

This forum is specified for all of seller and buyer's testimony summary. Also to improve their customer service operator, it is necessary for frontliner to focus on one customer until their problem solved in order to earn trust to customers. 


\section{International Journal of Science and Research (IJSR) \\ ISSN (Online): 2319-7064}

Index Copernicus Value (2015): 78.96 Impact Factor (2015): 6.391

\section{References}

[1] APJII. (2014). Profil Pengguna Internet Indonesia 2014. [Online]. Available

on http://www.slideshare.net/internetsehat/profil-penggunainternet-indonesia-2014-riset-oleh-apjii-dan-puskakomui. [Accessed: 28 Februari 2017].

[2] Cosseboom, Leighton. (2014). Indonesian online marketplace Tokopedia raises $\$ 100 \mathrm{M}$ from SoftBank and Sequoia." [Online]. Available on: https://www.techinasia.com/tokopedia-softbank-sequoiacapital-funding-news, [20 April 2017].

[3] Freischlad, Nadine. (2014),“ The rise of Indonesia's Tokopedia (infographic)." [Online]. Available on: https://www.techinasia.com/indonesias-tokopedia-turnstoday-infographic , [20 April 2017].

[4] Wijaya, Ketut Krina. (2014).“ Berusia 6 Tahun, Apa Saja Pencapaian Tokopedia?.” [Online]. Available on: https://id.techinasia.com/pencapaian-tokopedia-selama6-tahun, [20 April 2017].

[5] Liputan. (2016).“ Ulang Tahun ke-7, Tokopedia Bukukan Transaksi Triliunan Rupiahtahun-ke-7tokopedia-bukukan-transaksi-triliunan-rupiah." [Online]. Available on: http://lifestyle.liputan6.com/read/2580201/ulang-tahunke-7-tokopedia-bukukan-transaksi-triliunan-rupiah, [20 April 2017].

[6] Kotler, P., dan Keller, K. L. (2013). Marketing Management. England: Pearson.

[7] Jalilvand, M. R., dan Samiei, N. (2012). The effect of electronic word of mouth on brand image and purchase intention. Marketing Intelligence \& Planning, Vol. 30, Iss 4 pp. $460-476$.

[8] Kolsaker, A., \& Payne, C. (2002). Engendering trust in e-commerce: a study of gender-based concerns. Marketing Intelligence \& Planning, 20(4), 206-214.

[9] Goyette, I., Bergeron, J., dan Marticotte, F. (2010). eWOM Scale: Word-of-Mouth Measurement Scale for e-Services Context. Canadian Journal of Administrative Sciences, Vol. 27, pp. 5-23.

[10] Meskaran, F., Ismail, Z., dan Shanmugam, B. (2013). Online Purchase Intention: Effects of Trust and Security Perception. Australian Journal of Basic and Applied Sciences, Vol. 7, No 6, pp. 307-315.

[11] Chadwick, S.A. (2001). Communicating Trust in ECommerce Interactions. Management Communication Quarterly, Vol. 14, No 4, pp. 655-658.

[12] Belanger, F., Hiller, J.S., dan Smith, W.J. (2002). Trustworthiness in electronic commerce: the role of privacy, security, and site attributes. Journal of Strategic Information Systems, Vol. 11, pp. 245-270.

[13] Davis, F.D., dan Bagozzi, R. (1989). User Acceptance of Computer Technology: A Comparison of Two Theoretical Models. Management Science, Vol. 35, No 8, pp. 982-1003.

[14]Pavlou, P.A. (2003). Consumer Acceptance of Electronic Commerce: Integrating Trust and Risk with the Technology Acceptance Model. Busniness Process Management Journal, Vol. 9, Iss 6, pp. 652-671.

[15] Wang, L., Law, R., Guilet, B.D., Fong, D. (2015). Impact of hotel website quality on online booking intentions: eTrust as a mediator. International Journal of Hospitality Management, Vol. 47, pp. 108 - 115.

[16] Chang, M., Pang, C., Tran, J.M., Liu, T.S., dan Yen, D.C. (2015). Exploring user acceptance of an e-hospital service: An empirical study in Taiwan. Computer Standards \& Interfaces, Vol. 38, No 4, pp. 35-43.

[17] Freischlad, Nadine. (2017).“ Ecommerce still falls behind expectations in Indonesia. New report explores why." [Online]. Available on: https://www.techinasia.com/macquarie-indonesiaecommerce-2017-report. [20 April 2017].

\section{Author Profile}

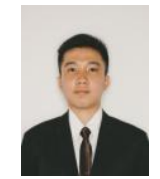

Rivan Ardyanto Sutoyo received the S.T. degrees in Informatics Engineering from Telkom University in 2015.

Volume 6 Issue 7, July 2017 www.ijsr.net 